\title{
A pilot study comparing superficial wound swab, deep tissue biopsy and fine needle aspiration biopsy in identifying infecting organisms in foot ulcers due to diabetes
}

\author{
Yusuf Bhabha', Paul Tinley ${ }^{2 *}$, Peter Davoren ${ }^{1}$, Petra Derrington ${ }^{1}$ \\ From Australasian Podiatry Council Conference 2011 \\ Melbourne, Australia. 26-29 April 2011
}

\section{Background}

Current clinical practice widely regards deep tissue biopsy as the gold standard for identification of wound bacterial bio-burden. This study aims to establish whether fine needle aspiration biopsy (FNAB) is as accurate as deep tissue biopsy and therefore offers a more accurate, cheaper and suitable alternative to routinely used superficial swab in diabetic wounds of varying depth and severity.

\section{Methods}

A total of 15 infected diabetic foot wounds were sampled and cultured. Three specimens were taken from each wound: superficial swab before debridement, followed by fine needle aspiration biopsy and deep tissue specimen at the end of sharp debridement.

\section{Results}

FNAB identified the same significant bacteria found in deep tissue culture in only 5 (33\%) wounds missing all or some significant bacterial isolates in $10(67 \%)$ wounds. In $6(40 \%)$ of these wounds FNAB cultures were negative. In comparison swab cultures identified the same significant bacterial isolates found in deep tissue culture in 13 (87\%) wounds, missing 1 bacterial isolate in 2 (13\%) wounds with no negative cultures recorded.

\section{Conclusions}

In this limited sample it would appear that FNAB culture technique is severely inadequate in identifying pathogens in diabetes foot wounds in comparison to

${ }^{2}$ Charles Sturt University, Albury, Australia

Full list of author information is available at the end of the article superficial swab technique and gold standard deep tissue biopsy. FNAB cultures missed microorganisms in two thirds of wounds and had a high false negative rate.

\section{Author details}

'Gold Coast Hospital, Southport, Australia. ${ }^{2}$ Charles Sturt University, Albury, Australia.

Published: 20 May 2011

doi:10.1186/1757-1146-4-S1-P4

Cite this article as: Bhabha et al:: A pilot study comparing superficial wound swab, deep tissue biopsy and fine needle aspiration biopsy in identifying infecting organisms in foot ulcers due to diabetes. Journal of Foot and Ankle Research 2011 4(Suppl 1):P4.
Submit your next manuscript to BioMed Central and take full advantage of:

- Convenient online submission

- Thorough peer review

- No space constraints or color figure charges

- Immediate publication on acceptance

- Inclusion in PubMed, CAS, Scopus and Google Scholar

- Research which is freely available for redistribution

Submit your manuscript at www.biomedcentral.com/submit
Ciomed Central

(c) 2011 Bhabha et al; licensee BioMed Central Ltd. This is an open access article distributed under the terms of the Creative Commons 